Univerza v Ljubljani

Filozofska fakulteta

brigita.kosevski@ff.uni-lj.si

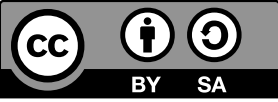

\title{
ALLES STIMMT! 1, 2, 3 IN 4
}

Marinka Krenker, Špela Novljan Potočnik, Andreja Retelj (2012) Alles stimmt! 1 (učbenik in delovni zvezek). Ljubljana: Založba Rokus Klett. ISBN 9612712069 in 9789612712075 , 111 strani in 151 strani, $17,50 €$ in $14,90 €$.

Marinka Krenker, Špela Novljan Potočnik, Andreja Retelj (2013) Alles stimmt! 2 (učbenik in delovni zvezek). Ljubljana: Založba Rokus Klett. ISBN 9612712751 in 9789612712747, 143 strani in 187 strani, $17,50 €$ in $14,90 €$.

Alexandra Kočevar, Špela Novljan Potočnik, Andreja Retelj (2014) Alles stimmt! 3 (učbenik in delovni zvezek). Ljubljana: Založba Rokus Klett. ISBN 9789612713669 in 9789612713676,135 strani in 163 strani, $17,50 €$ in $14,90 €$.

Tina Grmek, Alexandra Kočevar, Nataša Sever (2015) Alles stimmt! 4 (učbenik in delovni zvezek). Ljubljana: Založba Rokus Klett. ISBN 9789612716547 in 9789612716530, 127 strani in 151 strani, $17,50 €$ in $14,90 €$.

\section{UVOD}

Učbeniški komplet 1-4 Alles stimmt! je slovenska priredba učbeniškega kompleta DaF kompakt A1-B1. Deutsch als Fremdsprache für Erwachsene (Sander, Ilse in dr.), založbe Ernst Klett Verlag, Stuttgart. Gradivo je prirejeno v skladu z ustreznimi učnimi načrti za nemščino, stopnje težavnosti besedil in jezikovnih struktur pa sledijo Skupnemu evropskemu jezikovnemu okvirju (SEJO).

Komplet je namenjen začetnemu učenju in poučevanju nemščine na gimnazijah in srednjih tehniških oz. strokovnih šolah ter je potrjen s strani MZŠŠs.

Učbeniški komplet Alles stimmt! 1-4 sestavljajo učbenik, delovni zvezek in zgoščenka s slušnimi besedili in nalogami za posamezni letnik gimnazije oz. srednje tehniške in strokovne šole. Hkrati pa založba redno dopolnjuje komplet z novostmi, ki so večinoma brezplačno dosegljive na medmrežju. 
$\mathrm{V}$ gradivu je najmočneje zastopan komunikacijski pristop, kar precej nalog in vaj pa izhaja iz konstruktivistično usmerjenega didaktičnega pristopa.

\section{STRUKTURA POSAMEZNIH DELOV KOMPLETA}

Učbeniki vsebujejo šest do sedem lekcij s tematskimi sklopi, ki so predvideni tudi v veljavnem UN. Vsaka lekcija je zasnovana na kratkih zgodbah in pripetljajih protagonista. Na začetku vsake lekcije se dijaki in dijakinje seznanijo z doseganjem učnih ciljev v govornem in pisnem sporazumevanju ter pri usvajanju besedišča in jezikovnih struktur.

Sledi stran z vizualno spodbudo, ki ima funkcijo motivacije za aktiviranje predznanja $\mathrm{k}$ določeni temi.

Učbeniški komplet na posameznih nivojih prinaša naslednje poudarke:

- $\mathrm{A} 1$ - besedišče,

- A2 - strategije slušnega in bralnega razumevanja,

- $\quad$ B 1 - strategije za govorno in pisno sporočanje.

Vsaka lekcija je razdeljena na tri enote $(A, B, C)$, ki vsebujejo naloge in vaje k različnim vidikom določene teme ali posamezne jezikovne strukture. Na koncu vsake lekcije je pregled slovničnih struktur, jezikovnih sredstev in besedišča. Učbeniško gradivo omogoča hkratno razvijanje vseh jezikovnih zmožnosti in v obliki posebnih okvirčkov opozarja dijake na določene značilnosti nemščine, na primer okvirček TIPP, kjer so razložene jezikovne in strukturne posebnosti, INFO, ki ponuja dodatne informacije, in okvirček LS (Lernstrategien), ki ponuja priporočila za uspešno učenje s pomočjo določenih tehnik oz. učnih strategij.

Pri vsaki podtemi je dodana tabela, ki nudi sistematičen pregled jezikovnih struktur in njihovih posebnosti v nemščini. Le-te so še posebej poudarjene. Trem obravnavanim podtemam sledi poglavje Alles auf einen Blick, kjer so ponovno poudarjene najpomembnejše jezikovne strukture, jezikovna sredstva in besedišče (Wortschatz) iz aktualne lekcije. Naloge na koncu lekcije (Alles auf den zweiten Blick) so strukturirane podobno kot naloge pri jezikovnih izpitih in s tem še dodatno motivirajo dijake za učenje nemščine. Dijaki s pomočjo medkulturnih tem spoznajo nemško govoreča področja in se seznanijo tudi s kratkim pregledom zgodovine literarnega ustvarjanja v Nemčiji, kar se sicer zelo redko pojavlja v učbenikih za nemščino.

Po tri ali štiri lekcije v vsakem učbeniku imajo dodatek EXTRA, kjer se dijaki soočijo z različnimi besedili. Vsebinsko se ta besedila nanašajo predvsem na nemško govoreče države. Obravnavajo tudi takšne medkulturne teme, ki jih večina drugih učbenikov zanemarja, na primer zanimivosti najmanjše nemško govoreče države Liechtenstein ali besedila, ki so aktualna za dijake kot bodoče študente (program Erasmus). Za besedili vedno sledijo naloge za bralno razumevanje, povzemanje besedil ter transfer znanja. Jezikovne zmožnosti se 
medsebojno povezujejo v nalogah, tako da so približno enakomerno zastopane oz. so bolj izpostavljene v delovnem zvezku. To velja predvsem za pisno sporočanje.

Vsaka lekcija v učbeniku prinaša tudi nalogo za projektno delo ali nalogo z medpredmetno vsebino. Na koncu posameznega učbenika je tabela z nepravilnimi glagoli.

Delovni zvezki se dosledno nanašajo na učbenike, jih dopolnjujejo in poglabljajo vsebine, obravnavane pri posameznih lekcijah. Prav tako kot v posameznem učbeniku se tudi tukaj naloge nanašajo na podteme A, B, C. Pri vsaki lekciji je tudi poglavje Phonetik, ki nudi dodatno urjenje slušnega razumevanja in izgovarjave. Na koncu vsake lekcije so primeri slovničnih struktur in jezikovnih sredstev z razlago pravil. Sledi Glossar, slovarček, kjer dijaki sami prevedejo besede, ki se pojavijo v gradivu, oz. dodajo še svoje.

Vsaka lekcija v delovnem zvezku vsebuje tristopenjsko samoocenjevalno lestvico, kjer dijaki ocenijo svoje učne dosežke. Na koncu vsake enote je naloga s projektnim delom. Delovni zvezki vsebujejo tudi naloge, kjer dijaki in dijakinje med seboj primerjajo izraze v angleščini, nemščini in slovenščini, in številne naloge s slovarjem. Za tiste dijake, ki želijo še dodatne izzive za usvajanje znanja nemščine, so na voljo še težje naloge.

Avdiozgoščenke vsebujejo slušna besedila, naloge in vaje za ozaveščanje in usvajanje poslušanja in slušnega razumevanja ter pravilne izgovarjave. Posnetki so avtentični in zelo kakovostni, tako da jih učitelji lahko pri vsaki obravnavani temi uporabijo kot fonetične vaje, hkrati pa nudijo dijakom tudi možnost urjenja zmožnosti poslušanja in izgovarjave doma.

\section{DIDAKTIČNA IN METODIČNA USTREZNOST GRADIVA}

Pri priredbi učbeniškega kompleta Alles stimmt! so avtorice upoštevale vsa didaktična načela - od sistematičnosti in postopnosti, primernosti besedil starosti in interesom dijakov do načela individualizacije in socializacije, ki sta prav tako pogosto vključeni v naloge.

Učbeniki in delovni zvezki omogočajo motivacijo za učenje in zavestno usvajanje jezika. K temu dijake še posebej spodbujajo opisani učni cilji na začetku vsake lekcije in samoocenjevanje na koncu posamezne enote.

Naloge in vaje so zasnovane interaktivno in spodbujajo k medsebojni komunikaciji v nemščini. Pri sestavljanju nalog so avtorice upoštevale tudi najnovejše ugotovitve na področju didaktike tujih jezikov in temu primerno oblikovale posamezne naloge. To pomeni, da so v učbeniškem gradivu upoštevane sodobne oblike in metode učenja tujega jezika ter tudi preverjanja usvojenega znanja. Naloge so oblikovane tako, da razvijajo pri dijakih kompetence vseživljenjskega učenja: sporazumevalno zmožnost pri materinščini in pri tujem (nemškem) jeziku, digitalno pismenost (elektronska pošta in uporaba drugih medijev), matematično zmožnost (računanje), zmožnost učenja (strategije za lažje učenje in pomnjenje besedišča ali za hitrejše in uspešnejše usvajanje in obvladovanje jezikovnih struktur, delo s slovarji in enciklopedijami), zmožnosti medsebojnega komuniciranja (skupinsko 
delo, delo v parih, projektno učenje) in medkulturno zmožnost, ki je glede na tuji jezik in z njim povezane vsebine zastopana praktično povsod. Besedila in naloge spodbujajo tudi kulturno zavest in izražanje. Razvijanje in usvajanje omenjenih zmožnosti se uresničuje večinoma s sodobnimi oblikami učenja, kot so interaktivno učenje, sodelovalno učenje, samostojno učenje, hkrati pa dijake ves čas spodbujajo k osmišljanju lastnega procesa učenja tujega jezika s samoocenjevanjem in refleksijo o svojem napredku pri učenju nemščine. To refleksijo spodbuja predvsem samoocenjevanje na koncu vsake predelane lekcije.

Vseživljenjske kompetence lahko dijaki pridobivajo tudi s pomočjo medpredmetnega povezovanja. Nemška besedila in naloge se navezujejo predvsem na teme iz geografije, zgodovine, umetnostne zgodovine, slovenščine in matematike.

Medkulturnost se uresničuje s spoznavanjem nemško govorečih držav. Naloge spodbujajo tudi razvijanje odnosa do lastne kulture in identitete, saj so večkrat sestavljene tako, da zahtevajo informacije o Sloveniji, njeni družbi ter kulturi in spodbujajo refleksijo o lastnem jeziku. Besedila so vsebinsko in jezikovno primerna stopnji učenja in aktualna za obdobje mladostnikov.

Kljub komunikacijskemu pristopu se vse štiri jezikovne zmožnosti ves čas prepletajo, naloge zanje pa so enakomerno porazdeljene $\mathrm{v}$ učbeniku in delovnemu zvezku. Za razvijanje slušnega razumevanja je na voljo zgoščenka, kjer se naloge navezujejo prav tako neposredno na besedila $\mathrm{v}$ gradivu. Velik poudarek, ki je prav tako $\mathrm{v}$ skladu z najnovejšimi dognanji didaktike učenja in poučevanja tujih jezikov, je na slušnem usvajanju jezika, predvsem na izgovarjavi.

Usvajanje jezikovnih struktur je vpeto v sobesedila, zahtevnost raste glede na stopnjo usvojenega znanja, hkrati pa je njihova uporaba praktično naravnana, tako da dijaki vidijo neposredni smisel učenja nemščine. Širok nabor vsebinsko enakovrednih, po stopnji zahtevnosti pa različnih besedil, omogoča učiteljem tudi delno notranjo diferenciacijo pri pouku nemščine, kar je sicer prednost redkih učbenikov za nemščino.

Delovni zvezek dopolnjuje naloge v učbeniku pri vseh jezikovnih zmožnostih in jezikovnih strukturah. Slovnične vaje so zapisane v sobesedilu, kar priča o sodobnem pristopu obravnavanja jezikovnih struktur. Teme se v vsakem nadaljnjem učbeniku nadgrajujejo, večinoma pa dijaki spoznavajo nove tematike in novo besedišče. Vsebine besedil v učnih enotah dosledno sledijo temam iz veljavnih učnih načrtov in so zanimive za mladostnike, ker ne omogočajo samo jezikovnega dela z besedili, torej ne gre samo za bralno razumevanje, temveč imajo informacije iz besedil za mlade tudi uporabno vrednost. Hkrati takšne vsebine zagotavljajo tudi večjo pozornost in motivacijo dijakov za učenje nemščine. Hkrati z usvajanjem novih tematik opazimo tudi gradacijo jezikovnih struktur, ki se širi koncentrično. Nove strukture se navezujejo na že usvojene in se stopnjujejo do višje stopnje (do A1 do B1 po SEJO).

Navodila in razlaga za tvorbo slovničnih struktur so jasno nakazana in razložena. Delovni zvezek nudi tudi veliko nalog za usvajanje in urjenje pisne zmožnosti, predvsem pisnega sporočanja $\mathrm{v}$ obliki različnih vrst besedil, ki bi jih moral vsak, ki se uči tuji jezik s 
pričakovano stopnjo B1 po SEJO, tudi obvladati, ko konča šolanje (različne vrste pisem, obvestila, prošnje, pritožbe ipd.)

Vizualna podpora v učbeniku in delovnem zvezku (slike, fotografije, ilustracije, grafično oblikovanje tabel) je ustrezna in ima veliko izrazno vrednost. Slike so tesno povezane z vsebinami, ki jih podpirajo, hkrati pa omogočajo učitelju, da jih lahko uporabi za dodatne vaje in naloge. Vizualno gradivo v celoti služi kot opora razumevanju tujega jezika, hkrati pa spodbuja k aktivni uporabi nemščine pri pouku.

\section{ZAKLJUČEK}

Alles stimmt! je s svojim svežim pristopom velika pridobitev za učenje nemščine pri nas. Temelji na komunikacijskem pristopu in upošteva najsodobnejša didaktična načela in metode. Naloge razvijajo pri dijakih kompetence vseživljenjskega učenja in, kjer je to smiselno, omogočajo medpredmetno povezovanje. Besedila so praktično naravnana - dijaki takoj vidijo smisel učenja nemščine in njeno uporabnost. Odlična je tudi oblikovna podoba skupaj s slikovnim gradivom.

Učbeniški komplet Alles stimmt! hkrati ponuja še vrsto dodatnih gradiv, na primer učbenike $\mathrm{v}$ elektronski obliki z orodjarno in aktivne povezave do avdio- ali videoposnetkov ter spletnih strani s sorodno tematiko, priročnik za učitelje, kjer lahko najdemo predloge za notranjo diferenciacijo, rešitve nalog iz učbenika in delovnega zvezka, zapise avdio- in videoposnetkov, dodatne predloge za različne izvedbe nalog in za kopiranje, dodatne predloge za medpredmetne povezave, teste za preverjanje naučene snovi za posamezno lekcijo, ideje za projektno delo in naslove spletnih strani v povezavi z obravnavanimi temami.

Na spletu je tudi predlog letne priprave, kot so si ga zamislile avtorice. Učitelji ga lahko poljubno spreminjajo glede na potrebe svojega pouka.

Na spletni strani www.srednja.net so na voljo tudi dodatni učni listi za utrjevanje in nadgradnjo znanja, video vsebine k posameznim lekcijam in spletni kviz, s katerim dijaki lahko preverijo svoje znanje.

Za srednje strokovne šole so na voljo dodatni učni listi s poudarkom na strokovni nemščini za ekonomske tehnike ter gostinske in turistične šole. Učni listi razširijo in nadgradijo osnovno temo v učbeniku in prinašajo številne dodatne naloge za utrjevanje strokovnega besedišča.

Učbeniški komplet Alles stimmt! je eden izmed redkih učbenikov za nemščino na našem tržišču, ki je popolnoma usklajen z veljavnimi učnimi načrti. Njegovo kakovost pa zagotavljajo še vse ostale prednosti, ki so zgoraj opisane. Morda je pri kompletu nekoliko moteča le cena posameznega kompleta za en letnik - 32,40 evrov, kar pomeni za štiri letnike 129,60 evrov. 